\title{
Relationship between the Traditional Buddhist Culture and the Fluctuations of Corporate Performance
}

\author{
Min Xiao \\ School of Management, Jinan University, Guangzhou, China \\ Email: m13265911658_1@163.com
}

How to cite this paper: Xiao, M. (2018) Relationship between the Traditional Buddhist Culture and the Fluctuations of Corporate Performance. Modern Economy, 9, 1379-1399.

https://doi.org/10.4236/me.2018.98088

Received: July 6, 2018

Accepted: August 4, 2018

Published: August 7, 2018

Copyright $\odot 2018$ by author and Scientific Research Publishing Inc. This work is licensed under the Creative Commons Attribution International License (CC BY 4.0).

http://creativecommons.org/licenses/by/4.0/

\section{(c) (i) Open Access}

\begin{abstract}
After the financial crisis and stock price crash, more stakeholders are concerned about the performance of the company. With the rise of religious economics in recent years, the paper selected data from 2006-2016 for listed companies on the A-share main board. The study found that: 1) The stronger the traditional Buddhist culture of listed companies is, the smaller the fluctuation of corporate performance is; 2 ) Compared with state-owned enterprises, the negative impact of traditional Buddhist culture on fluctuations in corporate performance is stronger among non-state-owned enterprises; 3) When the company is in a mature period, the Buddhist tradition has a stronger inhibitory effect on corporate performance fluctuations.
\end{abstract}

\section{Keywords}

Buddhist Traditional Culture, Corporate Performance Fluctuation, Risk Aversion

\section{Introduction}

Enterprise performance volatility is an important indicator to measure the stability of a company's earnings. The existing research mainly discusses the factors affecting the fluctuation of enterprise performance from the level of corporate governance and other factors, but ignores the factors that affect the fluctuation of corporate performance from the non-institutional perspective. Generally speaking, in order to maximize the profit of the target company, the business managers of the enterprise will make some irrational decisions, such as formulating some strategies that violate the willingness of the enterprise to develop, or blindly pursuing the realization of short-term benefits while ignoring the actual long-term development, resulting in the fluctuations of corporate performance. 
Buddhism culture has always played an important role in the historical stage of China. From a micro perspective, traditional Buddhist culture, as an important spiritual civilization of our country, can affect individual personality and organizational/company development. From a macroscopic point of view, Buddhism has exerted a significant influence on the political, economic, social and cultural aspects of a certain region. This paper is based on the micro level to examine the impact of traditional Buddhist culture on corporate performance volatility. The article selects the data of the listed companies of A-share main board from 2006 to 2016 as the research sample. The research results show that the more traditional Buddhist culture atmosphere of the listed company is, the more stable the performance fluctuation of the company is. In addition, the article explains from a psychological perspective that the above relationship is more obvious in non-state-owned enterprises. At the same time, based on the perspective of the enterprise life cycle, the research results show that when the enterprises in the mature stage, the traditional culture of Buddhism inhibits the fluctuation of corporate performance more obviously. The research conclusions provide empirical evidence for understanding the fluctuation of corporate performance from the non-institutional level, and can also arouse scholars to pay attention to the role of informal institutional culture in the stable development of enterprises.

\section{The structure of This Paper and Literature Review}

\subsection{The Structure of This Paper}

The article is organized as follows:

The first part is the introduction. It mainly introduces the research background of the article and briefly summarizes the main contents of the article.

The second part is literature review. This section reviews relevant literature at home and abroad, including: existing research on corporate performance volatility; the impact of religious traditions on business conduct; and the relationship between religious traditions and formal institutions.

The third part is the theoretical analysis and hypothesis. This part mainly proposes three main hypotheses based on relevant theories.

The fourth part is the selection of samples and the measurement of variables. This section summarizes the source of the sample, as well as the measurement of related variables and the selection of control variables.

The fifth part is the model design. This section focuses on two main regression models.

The sixth part is the empirical result, which mainly analyzes the regression results.

The seventh part is the conclusion. The empirical results of this paper are summarized and the future research directions are proposed.

\subsection{The Connotation and Influencing Factors of Enterprise Performance Fluctuation}

Adams, Cheng et al. argue that company performance includes both perfor- 
mance levels and performance volatility. Performance levels measure the company's short-term performance, while performance volatility considers the company's long-term operating conditions, including the stability of company earnings [1] [2]. Kogan, Moscoviei et al. studied the influencing factors of corporate performance volatility from the perspective of decision theory. They claimed that team communication generated costs, and the larger the team, the more cost. The final team's decision was replaced by a compromise and compromise. Therefore, the larger the company, the more conservative the final decision may be, and the smaller the performance volatility. Adams et al. found that the power of other managers within the company was affected by the concentration of corporate power. If the company's power is too concentrated, then the company's performance and the market value of the company will fluctuate more. Cheng, Niu et al. have shown that board size has a negative correlation with corporate performance volatility [3].

Koemiadi et al. have shown that companies with better governance structures have lower non-systemic risks, and their performance volatility will be smaller. Yang et al. empirically examined the relationship between management decision-making authority and corporate performance volatility from the perspective of senior management team decision-making. The results of the study have found that a company with more authority in its position will have greater volatility in the performance of the company. Zang found that the higher the female directors, the more stable their performance fluctuations, because of female directors tending to avoid risks compared to male directors [4].

\subsection{The Impact of Religious Traditions on Individuals and Businesses}

Miller and Hoffmann found that the stronger the level of religious belief, the weaker people's ability to withstand risk. Osoba et al. found that risk averseers went to church more often than risk takers. Pan, Zhong found that family members with religious beliefs were more cautious in borrowing. Jiang et al. argued that founders with religious backgrounds were more inclined to avoid risks when making decisions. Hilary and Hui discovered that religion influences organizations' attitudes toward risk. Chen, $\mathrm{Du}$ et al. showed that the more religious traditions in the location of listed companies, the less accounting violations [5] [6]. Du et al. discovered that religious traditions promoted corporate social responsibility, and this promotion was more pronounced in areas where the external legal environment was weak [7]. In addition, Bi et al. found that traditional culture is positively related to the level of corporate environmental information disclosure, while there is a complementary effect between traditional culture and environmental systems. Gmbling propensity would be stronger in regions with higher concentrations of Catholics relative to Protestants [8]. 


\section{Theoretical Analysis and Hypothesis Proposed}

\subsection{Traditional Buddhist Culture and Corporate Risk Appetite}

Previous literature on religious traditions shows that people with traditional Buddhist cultural beliefs have a greater risk aversion tendency. Generally speaking, the risk decision of the enterprise is made by the company's management, and the traditional culture of Buddhism can influence the strategic choices and risk decisions made by the executives in the uncertain environment by influencing the executives' psychological and cognitive preferences, and ultimately affect the organizational behavior of the company. Therefore, the stronger the corporate traditional culture atmosphere of the enterprise, the weaker the risk-taking ability of the enterprise, and the higher the aversion of the enterprise to the risk, so that the senior executives often adopt some gentle strategies in making decisions, thus reducing the fluctuation of corporate performance. McGuire, Sean T, Omer, Thomas C et al. found that firms headquartered in areas with strong religious social norms generally experience lower incidences of financial reporting irregularities [9]. At the same time, according to the theory of resource dependence, enterprises in the process of sustainable development will minimize the dependence on external resources, thereby reducing the risk caused by the uncertainty of the external environment. Therefore, when the concept of traditional Buddhist culture conflicts with the decision of the enterprise, it will increase the cost of the enterprise. Stephen J. Nickell considered that competition is associated with a significantly higher rate of total factor productivity growth [10]. Therefore, from the perspective of social capital, when making decisions, companies will try to avoid behaviors that are inconsistent with the local style. On the contrary, they will pursue synergies and follow the local culture to minimize costs. From this perspective, it is necessary for corporate culture to be consistent with the local environment of the company. Therefore, if the traditional Buddhist culture of the company is more concentrated, the traditional Buddhist culture can restrain the opportunistic behavior of managers to a certain extent, thus restraining the fluctuation of corporate performance. Based on the above analysis, this paper proposes the following assumptions:

H1: The richer the traditional Buddhist atmosphere of the listed company, the smaller the fluctuation of corporate performance.

\subsection{Nature of Property Rights, Traditional Buddhist Culture and Fluctuations in Corporate Performance}

$\mathrm{Du}$ found that there is a complementary substitution between religious tradition and formal system. When the company faces a strong external supervision mechanism, the suppression of corporate governance by religious traditions tends to weaken [11]. Due to China's special institutional background, more than half of listed companies are state-owned enterprises, and different corporate natures have different internal corporate cultures, and China's state-owned enterprises have formed a unique corporate culture in the process of development. Com- 
pared with non-state-owned enterprises, state-owned enterprise culture may have some political color. Therefore, based on the theory of property rights nature, this paper explains whether there is a complementary substitution effect between different cultures of state-owned enterprises and non-state-owned enterprises from the perspective of psychology. Edward proposed conservatism, that is, when people make decisions in the face of uncertainty, if there is new information about decision-making, people may not change the original beliefs in a rational Bayesian way. Therefore, this paper believes that the management and employees in state-owned enterprises will subconsciously recognize the culture of state-owned enterprises, and give less weight to the culture outside the enterprise to avoid the risk uncertainty caused by the external environment. Therefore, this paper expects that the unique corporate culture within state-owned enterprises may dilute the inhibition of some Buddhist traditional culture on corporate performance fluctuations. Based on this, this paper proposes a second hypothesis:

$\mathrm{H} 2$ : Compared with state-owned enterprises, the negative influence of traditional Buddhist culture on corporate performance volatility is stronger in non-state-owned enterprises.

\subsection{Enterprise Life Cycle Path Hypothesis}

Wright argues that when a company is in the growth stage, it will undertake high-risk projects with expected returns and expected cash flow uncertainty. According to the enterprise life cycle theory, when the enterprise is in different life cycle stages, the internal and external environment and development strategy of the enterprise are different. With the gradual development of the enterprise, when the enterprise is in the mature stage, the free cash flow of the enterprise reaches the highest. At this time, the enterprise will increase investment, and at the same time, it will also increase the risk faced by the enterprise, and ultimately lead to excessive performance volatility. However, the Buddhist tradition will act as a stabilizer in the company's investment decisions, and to some extent inhibit the management's excessive investment and aggressive behavior, which is more likely to reduce performance volatility. Based on this, this paper proposes a third hypothesis:

H3: When the enterprise is in a mature stage, the traditional culture of Buddhism has a stronger inhibitory effect on the fluctuation of corporate performance.

\section{Sample Selection and Variable Measurement}

\subsection{Sample Selection and Data Source}

The sample covers China firms with fiscal year-ends over the period 2006 to 2016. I obtained nominal accounting variables from the CSMAR database. I obtain the latitude and longitude of the company registration and the key temple sites from Baidu Map and Google Map. For the initial data, this article has done 
the following processing:

1) Excluding $S T /{ }^{\star} S T$ companies in listed companies;

2) Considering the continuity of data, companies that were not listed before 2006 and companies that were delisted during 2006-2016 were excluded.

3) Eliminate the observations of listed companies in the financial and insurance industries and the lack of financial data.

4) In order to avoid the influence of other traditional cultures of a few ethnic groups on traditional Buddhist culture, following the practices of Chen, $\mathrm{Hu}, \mathrm{Du}$ et al., this article excludes listed companies whose registered places are located in ethnic minorities [12] [13]. At the same time, according to the "Report of the State Council's Bureau of Religious Affairs on the Determination of the National Key Temples of Buddhism in the Han Area" issued by the State Council of the People's Republic of China on April 9, 1983 which include 148 provincial key temples. In addition, I also added 56 key temples in the list of the second batch of national key temples of the Chinese Buddhist Association of Chinese Buddhism, a total of 204 key Buddhist temples. The final sample comprises 12088 observations, a total of 1327 listed companies. To mitigate the effects of outliers, I winsorize all continuous variables in Table 1 at the top or bottom one percentile of the deflated value in each year.

\subsection{Variable Selection and Measurement}

\subsubsection{Enterprise Performance Fluctuations}

This paper measures corporate performance volatility from two perspectives: accounting performance and market performance. ROA is selected as an indicator to measure the company's accounting performance. Tobin's $\mathrm{Q}$ is selected as an indicator to measure the company's market performance. The Tobin $\mathrm{Q}$ value is a comprehensive indicator that can more realistically reflect the performance of the company. Referring to the research methods of Adams, Cheng et al., I adopt Glejter heteroscedasticity test to measure the performance volatility of the company in stages. Therefore, the company's performance fluctuations are divided into vertical volatility and horizontal volatility. Vertical volatility mainly refers to changes in company performance during the research period, reflecting the continuity and stability of company performance (ROA, Tobin's Q). Horizontal volatility indicates the extent to which a company's performance deviates from normal performance, reflecting performance fluctuations between different companies [14]. The residual of model (3) takes the absolute value as a proxy variable to measure the company's lateral dispersion.

\subsubsection{Traditional Buddhist Culture}

According to the research ideas of Hilary and Hui, this paper uses the number of key Buddhist temples within a certain range of listed companies to measure the influence of traditional Buddhist culture on listed companies. I adopt the number of key Buddhist temples within $100 \mathrm{~km}, 200 \mathrm{~km}$, and $300 \mathrm{~km}$ of the company as a proxy variable for measuring traditional Buddhist culture. 


\subsubsection{Control Variables}

Following the previous scholars' research on company performance, I added control variables such as company size (C_size) and board size (Inboard) and other control variables to the model [15] [16] [17] [18]. Detailed variable definitions are shown in Table 1.

\section{Research Design}

\subsection{A Test Model for Analyzing the Relationship between Buddhist Traditional Culture and Corporate Performance Fluctuations}

In order to test $\mathrm{H} 1$, that is, the richer the traditional Buddhist atmosphere of the listed company, the smaller the fluctuation of corporate performance. This paper builds the following model based on two different performance volatility [19] [20]:

1) When testing the traditional culture of Buddhism and the vertical performance fluctuations of the company. The data on the control variables is the average value during the sample period. I estimate the following equation:

$$
\begin{gathered}
\text { Std_ROA }=a_{0}+a_{1} \text { rel } 200+\text { control Variables }+\varepsilon \\
\text { Std_Tobin's } Q=a_{0}+a_{1} \text { rel } 200+\text { control Variables }+\varepsilon
\end{gathered}
$$

In model (1) and model (2), the explanatory variable Std_ROA (Std_Tobin's Table 1. Main variable definition.

\begin{tabular}{|c|c|c|}
\hline Variable nature & Variable name & Variable description \\
\hline \multirow{3}{*}{$\begin{array}{l}\text { Dependent variable } \\
\text { (Accounting) }\end{array}$} & ROA & Return on Assets \\
\hline & Std_ROA & The standard deviation of performance during a company's research period \\
\hline & u_R & The extent to which actual performance deviates from normal performance \\
\hline \multirow{3}{*}{$\begin{array}{l}\text { Independent } \\
\text { variable } \\
\text { (Market) }\end{array}$} & TobinQ & Corporate Market Value/Asset Replacement Cost \\
\hline & Std_TobinQ & the standard deviation of performance during a company's research period \\
\hline & u_Q & The extent to which actual performance deviates from normal performance \\
\hline \multirow{6}{*}{$\begin{array}{l}\text { Independent } \\
\text { variable }\end{array}$} & rel100/rel200/rel300 & Number of key temples within $100 / 200 / 300 \mathrm{~km}$ of the registered company of the listed company \\
\hline & Dum (rel200) & When rel200 is greater than its mean value, it takes a value of 1 , otherwise it is 0 \\
\hline & lev & Liabilities/Assets \\
\hline & lnboard & The variable takes the logarithm of the board size \\
\hline & C_size & The variable takes the logarithm of the total assets \\
\hline & growth & Operating income growth rate \\
\hline \multirow{5}{*}{$\begin{array}{l}\text { Control } \\
\text { variable }\end{array}$} & seperation & The degree of separation of powers \\
\hline & H10 & Equity concentration, which is the sum of the squares of the shareholding ratio of the top 10 shareholders \\
\hline & SOE & Take 1 for the state-owned sample, otherwise take 0 \\
\hline & IND & Industry \\
\hline & age & Company establishment time \\
\hline
\end{tabular}

Q) measures the vertical volatility of the firm, mainly refers to the change of 
company performance during the research period, reflecting the continuity and stability of the company's performance. At the same time, the two models were tested with rel100 and rel300 as distance standards. If the coefficient $a_{1}$ is significantly negative, it indicates that the richer the traditional Buddhist atmosphere of the listed company, the smaller the fluctuation of corporate performance, the $\mathrm{H} 1$ is established.

2) When studying the relationship between traditional Buddhist culture and the horizontal performance volatility of the company, it is mainly divided into two stages: First, based on the company performance ROA (Tobin's Q) and the traditional influence of Buddhist culture (rel200) and related control variables, a simple linear regression is performed to obtain the residual $u 1$ ( $u 2$ ). Then the absolute value $\mathrm{u} \_\mathrm{R}\left(\mathrm{u} \_\mathrm{Q}\right)$ of the residual is regressed with the influence degree of Buddhist traditional culture (rel200) and the control variables. The specific analysis model is as follows:

$$
\begin{gathered}
\operatorname{ROA}(\text { Tobin's } \mathrm{Q})=a_{0}+a_{1} \text { rel } 200+\text { control Variables }+u 1(u 2) \\
\mathrm{u}_{-} \mathrm{R}\left(\mathrm{u}_{-} \mathrm{Q}\right)=a_{0}+a_{1} \text { rel } 200+\text { control Variables }+\varepsilon
\end{gathered}
$$

First, through the model (3), the ROA (Tobin's Q) and the explanatory variable and the control variable are subjected to multiple linear regression, and the residual $u 1(u 2)$ can be obtained, and then the absolute value of the residual $\mathrm{u} \_\mathrm{R}\left(\mathrm{u} \_\mathrm{Q}\right)$ is used to measure the lateral direction of the company. Discreteness, indicating the horizontal volatility of company performance.

Then, using the model (4), the absolute value $\mathrm{u}_{-} \mathrm{R}\left(\mathrm{u}_{-} \mathrm{Q}\right)$ of the residual is regressed with the Buddhist influence degree (rel200) and the control variable. If the coefficient of rel200 is significantly negative, the assumption 1 is established.

\subsection{Property Nature of the Enterprise}

Whether the influence of traditional Buddhist culture on corporate performance fluctuations is different between state-owned enterprises and non-state-owned enterprises.

In order to test $\mathrm{H} 2$, the article divides the sample into state-owned enterprises and non-state-owned enterprises by grouping, and the specific model is consistent with the model of hypothesis 1 [21].

\subsection{The Enterprise Life Cycle}

Most existing studies have simplified the enterprise life cycle into four phases: initial stage, growth stage, maturity stage, and recession stage. According to the characteristics of listed companies in China, this paper divides the life cycle of enterprises into three stages: growth stage, maturity stage and recession stage [22] [23].

Similarly, in order to verify H3, I divide the enterprise into four stages by cash flow combination method, and then use group regression to explore whether 
there is a difference in the influence of traditional Buddhist culture at different stages on corporate performance fluctuations.

\section{Descriptive Statistics and Empirical Results}

\subsection{Descriptive Statistics}

From Table 2 we can see that the mean values of the variables rel100, rel200 and rel300 for measuring the Buddhist tradition are 5.45, 12.46 and 21.84 and the standard deviations are 4.64, 9.04 and 14.62 respectively. It is explained that the average number of key Buddhist temples within $100 \mathrm{~km}$ and $200 \mathrm{~km}$ and $300 \mathrm{~km}$ of the listed company is about 5, 12 and 22 respectively. Taking rel200 as an example, the number of key Buddhist temples around the company can be up to 40 , and the minimum is 0 , indicating that there is a large gap between the traditional Buddhist atmospheres around different companies. The mean values of the control variables lev, C_size, and growth are $0.53,22.23$, and 0.23 and the standard deviations are $0.21,1.5$, and 0.79 , respectively, which are basically consistent with the existing literature [24] [25] [26] [27].

\subsection{Main Results}

\subsubsection{The Influence of Traditional Buddhist Culture on Corporate Performance Fluctuations}

First, we examine the impact of traditional Buddhist culture on corporate performance volatility. From enterprise level, after controlling for other factors such

Table 2. Descriptive statistics.

\begin{tabular}{|c|c|c|c|c|c|c|c|c|}
\hline variable & $\mathrm{N}$ & mean & sd & p25 & p50 & p75 & $\min$ & $\max$ \\
\hline Std_ROA & 12,088 & 0.04 & 0.03 & 0.02 & 0.03 & 0.05 & 0 & 0.20 \\
\hline Std_TobinQ & 12,088 & 1.07 & 1.01 & 0.45 & 0.73 & 1.25 & 0 & 6.57 \\
\hline $\mathrm{u} \_\mathrm{R}$ & 12,088 & 0.04 & 0.04 & 0.01 & 0.02 & 0.05 & 0 & 0.34 \\
\hline u_Q & 12,088 & 1.11 & 1.32 & 0.39 & 0.82 & 1.36 & 0 & 11.48 \\
\hline ROA & 12,088 & 0.03 & 0.06 & 0.01 & 0.03 & 0.06 & -0.27 & 0.20 \\
\hline TobinQ & 12,088 & 1.89 & 2.02 & 0.71 & 1.27 & 2.25 & 0.15 & 13.13 \\
\hline rel100 & 12,088 & 5.45 & 4.64 & 2 & 4 & 8 & 0 & 18 \\
\hline rel200 & 12,088 & 12.46 & 9.04 & 6 & 10 & 21 & 0 & 40 \\
\hline rel300 & 12,088 & 21.84 & 14.62 & 9 & 19 & 34 & 0 & 54 \\
\hline lev & 12,088 & 0.53 & 0.21 & 0.38 & 0.54 & 0.68 & 0.08 & 1.22 \\
\hline growth & 12,088 & 0.23 & 0.79 & -0.05 & 0.09 & 0.26 & -0.71 & 6.14 \\
\hline lnboard & 12,088 & 2.20 & 0.21 & 2.08 & 2.20 & 2.30 & 1.10 & 3.09 \\
\hline C_size & 12,088 & 22.23 & 1.50 & 21.24 & 22.07 & 23.05 & 18.96 & 27.27 \\
\hline seperation & 12,088 & 5.96 & 8.35 & 0 & 0 & 11.15 & 0 & 44.48 \\
\hline $\mathrm{H} 10$ & 12,088 & 0.20 & 0.16 & 0.08 & 0.15 & 0.26 & 0 & 0.86 \\
\hline SOE & 12,088 & 0.66 & 0.47 & 0 & 1 & 1 & 0 & 1 \\
\hline
\end{tabular}


as asset-liability ratio (lev), firm size (C_size), and growth (growth), the proxy variable of Buddhist traditional culture (rel200) is negatively correlated with the vertical and horizontal performance fluctuations of the enterprise, and the coefficient is significantly negative, consistent with the expectation. Then, we use rel100 and rel300 as the distance standard to measure the traditional culture of Buddhism. The regression results show that the rel100 coefficient is significantly negative when the firm performance fluctuation is measured by Std_ROA. However, when the dependent variable is Std_TobinQ, the coefficient of rel100 is marginal significantly. From the descriptive statistics in Table 3 , the average value of rel100 is only 5 , so it does not reflect the extent to which the company is influenced by traditional Buddhist culture. When rel300 is used as an explanatory

Table 3. The influence of Buddhism on corporate performance fluctuations.

Panel A (longitudinal dispersion)

\begin{tabular}{|c|c|c|c|c|c|c|}
\hline \multirow[b]{2}{*}{ rel100 } & \multicolumn{3}{|c|}{ Std_ROA } & \multicolumn{3}{|c|}{ Std_TobinQ } \\
\hline & $-0.0005^{\star * *}$ & & & $-0.0088^{\star}$ & & \\
\hline & $(-2.92)$ & & & $(-1.85)$ & & \\
\hline \multirow[t]{2}{*}{ rel200 } & & $-0.0003^{\star * *}$ & & & $-0.0067^{\star * *}$ & \\
\hline & & $(-3.21)$ & & & $(-2.90)$ & \\
\hline \multirow[t]{2}{*}{ rel300 } & & & $-0.0002^{\star * *}$ & & & $-0.0035^{\star *}$ \\
\hline & & & $(-3.46)$ & & & $(-2.49)$ \\
\hline \multirow[t]{2}{*}{ lev } & $0.0380^{* * *}$ & $0.0383^{* * *}$ & $0.0381^{\star * *}$ & $0.3253^{* *}$ & $0.3277^{\star *}$ & $0.3266^{* *}$ \\
\hline & (8.94) & (8.98) & (8.95) & $(2.29)$ & $(2.32)$ & $(2.32)$ \\
\hline \multirow[t]{2}{*}{ lnboard } & $-0.0078^{\star *}$ & $-0.0078^{\star *}$ & $-0.0077^{\star *}$ & -0.0868 & -0.0895 & -0.0858 \\
\hline & $(-2.34)$ & $(-2.35)$ & $(-2.32)$ & $(-0.94)$ & $(-0.97)$ & $(-0.93)$ \\
\hline \multirow[t]{2}{*}{ growth } & $0.0024^{* * *}$ & $0.0024^{* * *}$ & $0.0024^{\star * *}$ & $0.1116^{* * *}$ & $0.1113^{* * *}$ & $0.1116^{* * *}$ \\
\hline & $(4.94)$ & (4.99) & $(5.00)$ & $(7.36)$ & (7.40) & (7.41) \\
\hline \multirow[t]{2}{*}{ age } & $0.0008^{* * *}$ & $0.0008^{\star * *}$ & $0.0008^{* * *}$ & $0.0256^{* * *}$ & $0.0253^{\star * *}$ & $0.0248^{* * *}$ \\
\hline & $(4.02)$ & $(3.92)$ & (3.77) & $(4.33)$ & $(4.28)$ & $(4.21)$ \\
\hline \multirow[t]{2}{*}{ C_size } & $-0.0098^{* * *}$ & $-0.0098^{* * *}$ & $-0.0098^{\star * *}$ & $-0.3644^{\star * *}$ & $-0.3652^{\star * *}$ & $-0.3645^{\star * *}$ \\
\hline & $(-14.25)$ & $(-14.36)$ & $(-14.28)$ & $(-15.59)$ & $(-15.70)$ & $(-15.65)$ \\
\hline \multirow[t]{2}{*}{ seperation } & $-0.0001^{*}$ & -0.0001 & -0.0001 & 0.0005 & 0.0007 & 0.0006 \\
\hline & $(-1.65)$ & $(-1.57)$ & $(-1.64)$ & $(0.24)$ & $(0.31)$ & $(0.25)$ \\
\hline \multirow[t]{2}{*}{$\mathrm{H} 10$} & $0.0214^{* * *}$ & $0.0207^{* * *}$ & $0.0208^{\star * *}$ & $0.5378^{* * *}$ & $0.5248^{* * *}$ & $0.5261^{* * *}$ \\
\hline & $(4.64)$ & (4.48) & (4.49) & (3.99) & $(3.88)$ & $(3.90)$ \\
\hline Year(Ind) & Control & Control & Control & Control & Control & Control \\
\hline \multirow[t]{2}{*}{ _cons } & $0.2419^{* * *}$ & $0.2438^{* * *}$ & $0.2436^{* * *}$ & $8.6334^{* * *}$ & $8.6858^{\star * *}$ & $8.6687^{* * *}$ \\
\hline & $(15.20)$ & (15.36) & (15.35) & (16.65) & (16.78) & $(16.72)$ \\
\hline $\mathrm{N}$ & 12088 & 12088 & 12088 & 12088 & 12088 & 12088 \\
\hline adj. R-sq & 0.244 & 0.245 & 0.246 & 0.292 & 0.294 & 0.293 \\
\hline
\end{tabular}


Panel B (lateral dispersion)

\begin{tabular}{|c|c|c|c|c|c|c|}
\hline \multirow[b]{2}{*}{ rel100 } & \multicolumn{3}{|c|}{ u_R } & \multicolumn{3}{|c|}{$\mathrm{u} \_\mathrm{Q}$} \\
\hline & $-0.0003^{\star *}$ & & & $-0.0086^{\star *}$ & & \\
\hline & $(-2.52)$ & & & $(-2.13)$ & & \\
\hline \multirow[t]{2}{*}{ rel200 } & & $-0.0002^{\star * *}$ & & & $-0.0076^{\star * *}$ & \\
\hline & & $(-2.79)$ & & & $(-3.90)$ & \\
\hline \multirow[t]{2}{*}{ rel300 } & & & $-0.0001^{\star \star \star}$ & & & $-0.0036^{\star * *}$ \\
\hline & & & $(-2.58)$ & & & $(-3.03)$ \\
\hline \multirow[t]{2}{*}{ lev } & $0.0276^{* * *}$ & $0.0278^{\star * *}$ & $0.0278^{\star * *}$ & $0.3653^{*}$ & $0.3652^{\star *}$ & $0.3661^{* *}$ \\
\hline & $(6.29)$ & $(6.34)$ & $(6.33)$ & $(1.95)$ & (1.98) & $(1.98)$ \\
\hline \multirow[t]{2}{*}{ lnboard } & -0.0001 & -0.0001 & -0.0000 & 0.0666 & 0.0630 & 0.0676 \\
\hline & $(-0.04)$ & $(-0.04)$ & $(-0.01)$ & $(0.68)$ & $(0.64)$ & $(0.69)$ \\
\hline \multirow[t]{2}{*}{ growth } & $0.0009^{*}$ & $0.0009^{*}$ & $0.0009^{\star}$ & $0.0673^{* * *}$ & $0.0669^{* * *}$ & $0.0673^{* * *}$ \\
\hline & $(1.72)$ & $(1.72)$ & $(1.73)$ & $(3.58)$ & $(3.58)$ & (3.59) \\
\hline \multirow[t]{2}{*}{ age } & $0.0003^{* *}$ & $0.0003^{* *}$ & $0.0003^{* *}$ & $0.0084^{*}$ & 0.0080 & 0.0075 \\
\hline & $(2.28)$ & $(2.19)$ & $(2.09)$ & $(1.72)$ & $(1.64)$ & (1.53) \\
\hline \multirow[t]{2}{*}{ C_size } & $-0.0089^{* * *}$ & $-0.0090^{\star * *}$ & $-0.0090^{\star * *}$ & $-0.3638^{\star * *}$ & $-0.3645^{\star * *}$ & $-0.3638^{\star * *}$ \\
\hline & $(-13.37)$ & $(-13.45)$ & $(-13.40)$ & $(-10.85)$ & $(-10.93)$ & $(-10.90)$ \\
\hline \multirow[t]{2}{*}{ seperation } & -0.0001 & -0.0001 & -0.0001 & $-0.0068^{\star * *}$ & $-0.0066^{\star * *}$ & $-0.0067^{\star * *}$ \\
\hline & $(-1.35)$ & $(-1.28)$ & $(-1.33)$ & $(-3.02)$ & $(-2.95)$ & $(-3.01)$ \\
\hline \multirow[t]{2}{*}{$\mathrm{H} 10$} & $0.0237^{\star * *}$ & $0.0233^{* * *}$ & $0.0233^{* * *}$ & $0.7827^{\star * *}$ & $0.7704^{* * *}$ & $0.7716^{* * *}$ \\
\hline & $(5.55)$ & (5.44) & $(5.46)$ & $(6.76)$ & $(6.66)$ & $(6.67)$ \\
\hline Year(Ind) & Control & Control & Control & Control & Control & Control \\
\hline \multirow[t]{2}{*}{ _cons } & $0.2039^{\star * *}$ & $0.2051^{* * *}$ & $0.2047^{* * *}$ & $8.2002^{* * *}$ & $8.2627^{* * *}$ & $8.2363^{* * *}$ \\
\hline & (15.04) & (15.19) & (15.15) & (13.17) & (13.28) & $(13.22)$ \\
\hline $\mathrm{N}$ & 12170 & 12170 & 12170 & 12170 & 12170 & 12170 \\
\hline adj. R-sq & 0.111 & 0.111 & 0.111 & 0.142 & 0.143 & 0.142 \\
\hline
\end{tabular}

Note: 1$)^{* * *}, * *, *$ indicate significant at $1 \%, 5 \%$, and $10 \%$, respectively; 2$) t$ values in parentheses.

variable, the regression results are significant in both models, further confirming the establishment of $\mathrm{H} 1$.

\subsubsection{The Nature of Property Rights, Traditional Buddhist Culture and Fluctuations in Corporate Performance}

In order to verify Hypothesis 2, I first classify the sample into a state-owned sample group and a non-state-owned sample group according to the actual controller nature. Then, using the two models of vertical and horizontal dispersion to carry out regression analysis on the state-owned sample group and the non-state-owned sample group respectively, the regression results in Table 4 show that in the two models, the coefficient of the proxy variable rel200 of the traditional Buddhist culture is significantly negative. Moreover, the coefficient 
test results of state-owned samples and non-state-owned samples indicate that there is a significant difference between the two, indicating that the traditional culture of Buddhism has a stronger inhibitory effect on the performance fluctuations of non-state-owned sample enterprises. The regression results of other control variables are consistent with the previous basic analysis. From another point of view, the internal culture of state-owned enterprises will dilute a part of the traditional culture of Buddhism to inhibit the fluctuation of corporate performance to a certain extent, indicating that there is a complementary substitution between different cultures [28].

\subsubsection{Dynamic Regression Analysis Based on Enterprise Life Cycle}

Most of the previous studies have used listed companies as a research sample

Table 4. Regression results for state-owned and non-state-owned samples.

Panel A (longitudinal dispersion)

\begin{tabular}{|c|c|c|c|c|c|c|}
\hline \multirow{2}{*}{ VARIABLES } & \multicolumn{3}{|c|}{ Std_ROA } & \multicolumn{3}{|c|}{ Std_TobinQ } \\
\hline & Full samples & State-owned & Non-state-owned & Full samples & State-owned & Non-state-owned \\
\hline \multirow[t]{2}{*}{ rel200 } & $-0.000^{* * *}$ & $-0.005^{\star * *}$ & $-0.012^{\star * \star}$ & $-0.007^{\star * *}$ & $-0.004^{\star * *}$ & $-0.010^{\star * *}$ \\
\hline & $(-3.21)$ & $(-3.01)$ & $(-6.95)$ & $(-2.90)$ & $(-3.96)$ & $(-6.43)$ \\
\hline \multirow[t]{2}{*}{ lev } & $0.038^{\star * *}$ & $0.034^{\star * \star}$ & $0.043^{* * *}$ & $0.328^{\star *}$ & 0.044 & $0.705^{\star * *}$ \\
\hline & $(8.98)$ & $(20.97)$ & $(18.38)$ & $(2.32)$ & $(1.00)$ & (10.09) \\
\hline \multirow[t]{2}{*}{ lnboard } & $-0.008^{\star *}$ & $-0.007^{\star * *}$ & $-0.006^{\star *}$ & -0.090 & -0.040 & 0.048 \\
\hline & $(-2.35)$ & $(-4.20)$ & $(-2.44)$ & $(-0.97)$ & $(-0.95)$ & $(0.64)$ \\
\hline \multirow[t]{2}{*}{ growth } & $0.002^{* * *}$ & 0.001 & $0.003^{* * *}$ & $0.111^{\star * *}$ & $0.078^{\star * *}$ & $0.115^{\star * *}$ \\
\hline & (4.99) & $(1.60)$ & $(6.90)$ & $(7.40)$ & $(6.16)$ & $(7.54)$ \\
\hline \multirow[t]{2}{*}{ C_size } & $-0.010^{* * *}$ & $-0.007^{\star * *}$ & $-0.015^{\star * *}$ & $-0.365^{\star * *}$ & $-0.242^{* * *}$ & $-0.548^{* * *}$ \\
\hline & $(-14.36)$ & $(-25.45)$ & $(-32.94)$ & $(-15.70)$ & $(-33.74)$ & $(-40.57)$ \\
\hline \multirow[t]{2}{*}{ seperation } & -0.000 & $-0.000^{* * *}$ & -0.000 & 0.001 & 0.000 & $-0.004^{* *}$ \\
\hline & $(-1.57)$ & $(-2.84)$ & $(-1.42)$ & $(0.31)$ & $(0.28)$ & $(-2.22)$ \\
\hline \multirow[t]{2}{*}{$\mathrm{H} 10$} & $0.021^{* * *}$ & $0.026^{\star * *}$ & -0.004 & $0.525^{\star \star *}$ & $0.530^{\star * *}$ & $0.598^{\star * *}$ \\
\hline & $(4.48)$ & (13.17) & $(-0.82)$ & (3.88) & $(9.87)$ & (4.38) \\
\hline \multirow[t]{2}{*}{ age } & $0.001^{* * *}$ & $0.001^{\star * *}$ & $0.001^{* * *}$ & $0.025^{\star * *}$ & $0.015^{\star * *}$ & $0.037^{* * *}$ \\
\hline & $(3.92)$ & $(9.12)$ & $(5.53)$ & $(4.28)$ & $(6.86)$ & (9.74) \\
\hline Year(Ind) & Control & Control & Control & Control & Control & Control \\
\hline \multirow[t]{2}{*}{ _cons } & $0.244^{* * *}$ & $0.182^{\star * *}$ & $0.339^{* * *}$ & $8.686^{* * *}$ & $5.921^{* * *}$ & $12.329^{* * *}$ \\
\hline & (15.36) & $(28.72)$ & (33.33) & (16.78) & $(34.86)$ & (40.08) \\
\hline $\mathrm{N}$ & 12088 & 7965 & 4123 & 12088 & 7965 & 4123 \\
\hline adj. R-sq & 0.245 & 0.216 & 0.326 & 0.294 & 0.221 & 0.394 \\
\hline \multirow[t]{2}{*}{$\mathrm{t}$} & & 13.50 & & & 14.30 & \\
\hline & & $(0.004)$ & & & $(0.002)$ & \\
\hline
\end{tabular}


Panel B (lateral dispersion)

\begin{tabular}{|c|c|c|c|c|c|c|}
\hline \multirow{2}{*}{ VARIABLES } & \multicolumn{3}{|c|}{$\mathrm{u} \_\mathrm{R}$} & \multicolumn{3}{|c|}{ u_Q } \\
\hline & Full sample & State-owned & Non-State-owned & Full sample & State-owned & Non-State-owned \\
\hline \multirow[t]{2}{*}{ rel200 } & $-0.000^{* * *}$ & $-0.000^{* * *}$ & $-0.008^{* * *}$ & $-0.008^{* * *}$ & $-0.006^{* * *}$ & $-0.011^{* * *}$ \\
\hline & $(-2.74)$ & $(-3.60)$ & $(-6.82)$ & $(-3.91)$ & $(-4.60)$ & $(-4.58)$ \\
\hline \multirow[t]{2}{*}{ lev } & $0.028^{* * *}$ & $0.020^{* * *}$ & $0.038^{* * *}$ & $0.389^{* *}$ & 0.004 & $0.899^{* * *}$ \\
\hline & $(6.28)$ & $(9.46)$ & $(12.02)$ & (2.10) & $(0.07)$ & $(8.29)$ \\
\hline \multirow[t]{2}{*}{ lnboard } & 0.000 & 0.000 & 0.003 & 0.068 & 0.066 & $0.225^{*}$ \\
\hline & $(0.02)$ & $(0.16)$ & $(0.95)$ & $(0.69)$ & (1.13) & $(1.94)$ \\
\hline \multirow[t]{2}{*}{ growth } & $0.001^{*}$ & 0.000 & 0.001 & $0.069^{* * *}$ & $0.065^{* * *}$ & $0.049^{* *}$ \\
\hline & (1.66) & $(0.72)$ & (1.14) & $(3.71)$ & (3.73) & $(2.06)$ \\
\hline \multirow[t]{2}{*}{ C_size } & $-0.009^{\star * *}$ & $-0.006^{* * *}$ & $-0.013^{\star * *}$ & $-0.362^{\star * *}$ & $-0.201^{\star * *}$ & $-0.662^{\star * *}$ \\
\hline & $(-13.40)$ & $(-17.72)$ & $(-21.87)$ & $(-10.79)$ & $(-20.44)$ & $(-31.56)$ \\
\hline \multirow[t]{2}{*}{ seperation } & -0.000 & -0.000 & $-0.000^{* * *}$ & $-0.006^{\star * *}$ & $-0.008^{\star * *}$ & -0.001 \\
\hline & $(-1.30)$ & $(-1.17)$ & $(-2.73)$ & $(-2.85)$ & $(-5.55)$ & $(-0.41)$ \\
\hline \multirow[t]{2}{*}{$\mathrm{H} 10$} & $0.023^{* * *}$ & $0.023^{* * *}$ & $0.031^{* * *}$ & $0.761^{* * *}$ & $0.625^{* * *}$ & $1.071^{* * *}$ \\
\hline & (5.38) & (8.58) & (5.07) & $(6.50)$ & (8.48) & $(5.05)$ \\
\hline \multirow[t]{2}{*}{ age } & $0.000^{* \star}$ & $0.000^{* * *}$ & -0.000 & $0.009^{\star}$ & 0.003 & $0.010^{*}$ \\
\hline & (2.09) & $(4.23)$ & $(-0.20)$ & $(1.73)$ & (1.15) & $(1.75)$ \\
\hline Year(Ind) & Control & Control & Control & Control & Control & Control \\
\hline \multirow[t]{2}{*}{ _cons } & $0.205^{* * *}$ & $0.151^{* * *}$ & $0.284^{* * *}$ & $8.189^{* * *}$ & $5.036^{* * *}$ & $13.717^{* * *}$ \\
\hline & $(15.06)$ & $(18.01)$ & (20.56) & (13.03) & $(21.62)$ & $(28.74)$ \\
\hline $\mathrm{N}$ & 12088 & 7965 & 4123 & 12088 & 7965 & 4123 \\
\hline adj. R-sq & 0.111 & 0.084 & 0.150 & 0.143 & 0.085 & 0.253 \\
\hline \multirow[t]{2}{*}{$\mathrm{t}$} & & 5.15 & & & 4.34 & \\
\hline & & $(0.0274)$ & & & $(0.0371)$ & \\
\hline
\end{tabular}

Note: 1$)^{* * *}, * *, *$ indicate significant at $1 \%, 5 \%$, and $10 \%$, respectively; 2$) \mathrm{t}$ values in parentheses.

from a static perspective, ignoring the differences between enterprises at different stages of life cycle. In view of this, this paper introduces the enterprise life cycle theory, attempts to analyze the relationship between traditional Buddhist culture and corporate performance volatility, and attempts to provide a reference for the dynamic construction of non-institutional culture in the different life cycle stages of enterprises. According to the characteristics of listed companies in China, this paper divides the life cycle of enterprises into three stages: growth stage, maturity stage and recession stage. The division of the life cycle is based on the practices of Cao Yu et al. and Dickinson, and is divided by the cash flow combination method. The regression results in Table 5 indicate that when the enterprise is at the maturity stage of the life cycle, the inhibitory effect of traditional Buddhist culture (rel200) on corporate performance volatility is signifi- 
cantly negatively correlated in both models, that is, when the enterprise is in a mature stage, the traditional culture of Buddhism has a stronger inhibitory effect on the fluctuation of corporate performance.

\subsection{Additional Test}

This section examines the sensitivity of the division of the enterprise life cycle. First, we use the multivariate scoring method to divide the enterprise life cycle stage, and then consider the factors of the difference between the industries, that is, according to the total score of the four indicators, the total sample is sorted by industry from large to small. Each industry sample is divided into three parts according to the total score size. About $1 / 3$ of the highest scores are for long-term enterprises. About $1 / 3$ of the lowest scores are enterprises in the recession period, and the middle part is mature enterprises. The multi-index comprehensive scoring method can comprehensively characterize the different development stages of the

Table 5. Different life cycle stages of the enterprise.

Panel A (longitudinal dispersion)

\begin{tabular}{|c|c|c|c|c|c|c|}
\hline \multirow{2}{*}{ VARIABLES } & \multicolumn{3}{|c|}{ Std_ROA } & \multicolumn{3}{|c|}{ Std_TobinQ } \\
\hline & Growth & Maturity & Recession & Growth & Maturity & Recession \\
\hline \multirow[t]{2}{*}{ rel200 } & -0.000 & $-0.000^{* * *}$ & $-0.000^{\star *}$ & -0.002 & $-0.009^{* * *}$ & $-0.010^{\star *}$ \\
\hline & $(-0.97)$ & $(-2.99)$ & $(-2.14)$ & $(-0.81)$ & $(-3.40)$ & $(-2.53)$ \\
\hline \multirow[t]{2}{*}{ lev } & $0.030^{\star * *}$ & $0.040^{\star * *}$ & $0.054^{\star * *}$ & -0.208 & $0.327^{\star \star}$ & $0.629^{\star * *}$ \\
\hline & $(4.31)$ & $(9.04)$ & $(11.83)$ & $(-1.36)$ & $(2.02)$ & (3.99) \\
\hline \multirow[t]{2}{*}{ lnboard } & $-0.008^{*}$ & -0.007 & -0.004 & -0.090 & -0.160 & -0.008 \\
\hline & $(-1.94)$ & $(-1.44)$ & $(-0.59)$ & $(-0.93)$ & $(-1.38)$ & $(-0.04)$ \\
\hline \multirow[t]{2}{*}{ growth } & $0.005^{\star \star \star}$ & $0.003^{\star \star *}$ & $0.002^{\star *}$ & $0.156^{\star * \star}$ & $0.074^{\star * *}$ & $0.111^{\star \star \star}$ \\
\hline & $(5.92)$ & $(3.61)$ & $(2.10)$ & $(5.76)$ & $(2.96)$ & $(4.37)$ \\
\hline \multirow[t]{2}{*}{ C_size } & $-0.007^{\star \star *}$ & $-0.009^{\star * \star}$ & $-0.015^{\star \star \star}$ & $-0.253^{\star \star *}$ & $-0.307^{\star * *}$ & $-0.579^{\star * \star}$ \\
\hline & $(-7.69)$ & $(-12.35)$ & $(-13.39)$ & $(-10.37)$ & $(-10.84)$ & $(-16.09)$ \\
\hline \multirow[t]{2}{*}{ age } & $0.001^{\star * \star}$ & $0.001^{\star * \star}$ & 0.001 & $0.027^{\star \star \star}$ & $0.017^{\star \star *}$ & $0.026^{\star *}$ \\
\hline & $(4.86)$ & $(4.30)$ & $(1.45)$ & $(3.78)$ & $(2.62)$ & $(2.56)$ \\
\hline \multirow[t]{2}{*}{$\mathrm{H} 10$} & $0.034^{\star * *}$ & $0.025^{\star * \star}$ & $0.018^{\star *}$ & $0.726^{* * *}$ & $0.545^{\star * *}$ & $0.391^{*}$ \\
\hline & (4.69) & $(3.90)$ & $(2.26)$ & $(4.55)$ & (3.53) & (1.66) \\
\hline \multirow[t]{2}{*}{ seperation } & $-0.000^{*}$ & $-0.000^{*}$ & 0.000 & -0.001 & -0.001 & $0.007^{\star}$ \\
\hline & $(-1.67)$ & $(-1.82)$ & $(0.20)$ & $(-0.27)$ & $(-0.45)$ & $(1.87)$ \\
\hline Year(Ind) & Control & Control & Control & Control & Control & Control \\
\hline \multirow[t]{2}{*}{ _cons } & $0.174^{\star * *}$ & $0.226^{\star * *}$ & $0.337^{\star * *}$ & $6.154^{* * *}$ & $7.661^{* * *}$ & $13.091^{* * *}$ \\
\hline & $(9.40)$ & (12.57) & $(12.42)$ & (12.11) & (13.07) & (15.44) \\
\hline $\mathrm{N}$ & 3689 & 4344 & 2878 & 3689 & 4344 & 2878 \\
\hline adj. R-sq & 0.180 & 0.270 & 0.369 & 0.247 & 0.272 & 0.389 \\
\hline
\end{tabular}


Panel B (lateral dispersion)

\begin{tabular}{|c|c|c|c|c|c|c|}
\hline \multirow{2}{*}{ VARIABLES } & \multicolumn{3}{|c|}{$\mathrm{u} \_\mathrm{R}$} & \multicolumn{3}{|c|}{ u_Q } \\
\hline & Growth & Maturity & Recession & Growth & Maturity & Recession \\
\hline \multirow[t]{2}{*}{ rel200 } & 0.000 & $-0.000^{\star * *}$ & -0.000 & -0.003 & $-0.011^{* * *}$ & -0.005 \\
\hline & $(0.31)$ & $(-2.94)$ & $(-1.11)$ & $(-1.35)$ & $(-3.47)$ & $(-1.44)$ \\
\hline \multirow[t]{2}{*}{ lev } & $0.013^{*}$ & $0.038^{* * *}$ & $0.059^{* * *}$ & -0.211 & $0.625^{*}$ & $0.968^{\star * *}$ \\
\hline & $(1.84)$ & $(5.62)$ & (10.41) & $(-0.89)$ & (1.93) & $(4.20)$ \\
\hline \multirow[t]{2}{*}{ lnboard } & -0.003 & -0.004 & $0.010^{*}$ & 0.111 & -0.141 & 0.189 \\
\hline & $(-0.86)$ & $(-0.82)$ & (1.65) & $(1.00)$ & $(-0.89)$ & (1.07) \\
\hline \multirow[t]{2}{*}{ growth } & $0.004^{* * *}$ & 0.000 & 0.000 & $0.118^{\star * *}$ & $0.083^{\star}$ & 0.052 \\
\hline & $(7.05)$ & $(0.10)$ & $(0.09)$ & (3.59) & (1.68) & $(1.57)$ \\
\hline \multirow[t]{2}{*}{ C_size } & $-0.004^{* * *}$ & $-0.008^{* * *}$ & $-0.015^{\star * *}$ & $-0.232^{* * *}$ & $-0.284^{* * *}$ & $-0.640^{* * *}$ \\
\hline & $(-5.43)$ & $(-8.88)$ & $(-13.40)$ & $(-6.46)$ & $(-5.99)$ & $(-12.63)$ \\
\hline \multirow[t]{2}{*}{ age } & 0.000 & 0.000 & -0.000 & -0.005 & 0.003 & $0.017^{\star *}$ \\
\hline & $(0.54)$ & $(1.23)$ & $(-0.10)$ & $(-0.82)$ & $(0.41)$ & (1.99) \\
\hline \multirow[t]{2}{*}{$\mathrm{H} 10$} & $0.014^{* *}$ & $0.025^{* * *}$ & $0.016^{\star *}$ & $0.780^{\star * *}$ & $0.821^{\star * \star}$ & $0.710^{\star * *}$ \\
\hline & $(2.35)$ & $(3.82)$ & (1.99) & $(4.92)$ & $(4.53)$ & $(3.62)$ \\
\hline \multirow[t]{2}{*}{ seperation } & -0.000 & -0.000 & -0.000 & $-0.005^{\star *}$ & $-0.008^{\star *}$ & -0.004 \\
\hline & $(-0.06)$ & $(-0.78)$ & $(-1.11)$ & $(-2.07)$ & $(-2.26)$ & $(-1.17)$ \\
\hline Year(Ind) & Control & Control & Control & Control & Control & Control \\
\hline \multirow[t]{2}{*}{ _cons } & $0.111^{* * *}$ & $0.205^{\star * *}$ & $0.296^{\star * *}$ & $5.815^{\star * *}$ & $7.019^{* * *}$ & $12.911^{* * *}$ \\
\hline & $(7.16)$ & $(9.66)$ & (12.10) & $(8.49)$ & $(7.75)$ & (13.03) \\
\hline $\mathrm{N}$ & 3689 & 4344 & 2878 & 3608 & 4211 & 2715 \\
\hline adj. R-sq & 0.065 & 0.124 & 0.224 & 0.115 & 0.131 & 0.263 \\
\hline
\end{tabular}

Note: 1$)^{* * *},{ }^{* *},{ }^{*}$ indicate significant at $1 \%, 5 \%$, and $10 \%$, respectively; 2 ) $t$ values in parentheses.

Table 6. Standards for the division of the enterprise life cycle.

\begin{tabular}{ccccccccc}
\hline \multicolumn{2}{c}{ VARIABLES } & $\begin{array}{c}\text { operating income } \\
\text { growth rate }\end{array}$ & $\begin{array}{c}\text { retained earnings } \\
\text { rate }\end{array}$ & $\begin{array}{c}\text { capital } \\
\text { expenditure rate }\end{array}$ & Age \\
\hline $\begin{array}{c}\text { Development stage feature } \\
\text { value }\end{array}$ & feature & value & feature & value & feature & value \\
Growth stage & High & 3 & Low & 3 & High & 3 & Low & 3 \\
Maturity stage & Mid & 2 & Mid & 2 & Mid & 2 & Mid & 2 \\
Recession stage & Low & 1 & High & 1 & Low & 1 & High & 1 \\
\hline
\end{tabular}

enterprise, and the loss of the sample is relatively small.

The regression results in Table 6 show that when the enterprise is in the mature stage of the life cycle, the inhibition effect of the traditional culture of Buddhism (rel200) on the fluctuation of enterprise performance is significantly negatively correlated in both models, and the hypothesis $\mathrm{H} 3$ is verified. The regression results in Table 7 are basically consistent with the regression results of 
the enterprise life cycle by using the cash flow method, indicating that the research conclusions based on the division method of the enterprise life cycle stage constructed by the Institute are robust.

\subsection{Robustness Test}

This paper conducted a series of robustness tests: 1) Dividing the sample into East, Central and Western regions according to the location of the company. Previous literatures have shown that the geographical distribution of Buddhism is largely consistent with the regional distribution of the economy. Therefore, it is inferred that the traditional Buddhist culture in the eastern region is more intense. The empirical results show that in the two models, the company is located in the eastern region. Buddhist tradition has a significant negative impact on its corporate performance volatility. 2) Defining rel200 as a dummy variable. The

Table 7. Comprehensive scoring method to divide business life cycle.

Panel A (longitudinal dispersion)

\begin{tabular}{|c|c|c|c|c|c|c|}
\hline \multirow{2}{*}{$\begin{array}{c}\text { VARIABLE } \\
\mathrm{S}\end{array}$} & \multicolumn{3}{|c|}{ Std_ROA } & \multicolumn{3}{|c|}{ Std_TobinQ } \\
\hline & $\begin{array}{l}\text { Growth } \\
\text { stage }\end{array}$ & $\begin{array}{l}\text { Maturity } \\
\text { stage }\end{array}$ & $\begin{array}{c}\text { Recession } \\
\text { stage }\end{array}$ & $\begin{array}{l}\text { Growth } \\
\text { stage }\end{array}$ & $\begin{array}{l}\text { Maturity } \\
\text { stage }\end{array}$ & $\begin{array}{c}\text { Recession } \\
\text { stage }\end{array}$ \\
\hline \multirow[t]{2}{*}{ rel200 } & -0.000 & -0.000 & $-0.000^{* * *}$ & -0.002 & $-0.007^{\star *}$ & $-0.009^{* * *}$ \\
\hline & $(-0.72)$ & $(-1.43)$ & $(-3.34)$ & $(-0.67)$ & $(-2.47)$ & $(-3.05)$ \\
\hline \multirow[t]{2}{*}{ lev } & $0.033^{* * *}$ & $0.047^{\star * *}$ & $0.050^{* * *}$ & $-0.464^{\star * *}$ & $0.268^{\star}$ & $0.752^{* * *}$ \\
\hline & (5.47) & (10.33) & (11.07) & $(-3.01)$ & $(1.80)$ & (5.07) \\
\hline \multirow[t]{2}{*}{ lnboard } & $-0.009^{\star \star}$ & $-0.009^{\star *}$ & -0.007 & -0.073 & -0.057 & -0.160 \\
\hline & $(-2.09)$ & $(-2.04)$ & $(-1.32)$ & $(-0.63)$ & $(-0.51)$ & $(-1.17)$ \\
\hline \multirow[t]{2}{*}{ growth } & $0.004^{* * *}$ & $0.003^{* * *}$ & 0.001 & $0.149^{* * *}$ & $0.113^{* * *}$ & 0.019 \\
\hline & $(5.07)$ & (4.19) & $(0.43)$ & (5.93) & (5.14) & $(0.55)$ \\
\hline \multirow[t]{2}{*}{ C_size } & $-0.007^{* * *}$ & $-0.011^{\star * *}$ & $-0.013^{\star * *}$ & $-0.222^{* * *}$ & $-0.368^{\star * *}$ & $-0.454^{* * *}$ \\
\hline & $(-7.94)$ & $(-13.54)$ & $(-13.87)$ & $(-8.11)$ & $(-13.66)$ & $(-15.12)$ \\
\hline \multirow[t]{2}{*}{ H10 } & $0.033^{\star * *}$ & $0.029^{\star * *}$ & $0.028^{\star * *}$ & $0.519^{\star * \star}$ & $0.549^{* * *}$ & $0.417^{\star \star}$ \\
\hline & (3.59) & $(5.28)$ & (3.68) & $(2.90)$ & $(3.41)$ & $(2.05)$ \\
\hline \multirow{2}{*}{ seperation } & -0.000 & -0.000 & -0.000 & -0.002 & 0.002 & 0.002 \\
\hline & $(-1.05)$ & $(-0.66)$ & $(-1.62)$ & $(-0.57)$ & $(0.67)$ & $(0.77)$ \\
\hline \multirow[t]{2}{*}{ age } & $0.001^{* * *}$ & $0.001^{* * *}$ & $0.001^{\star * *}$ & $0.024^{\star \star \star}$ & $0.032^{\star * *}$ & $0.033^{\star * *}$ \\
\hline & $(4.68)$ & $(5.14)$ & $(2.63)$ & $(2.97)$ & $(4.29)$ & $(3.60)$ \\
\hline Year(Ind) & Control & Control & Control & Control & Control & Control \\
\hline \multirow[t]{2}{*}{ _cons } & $0.179^{* * *}$ & $0.254^{* * *}$ & $0.298^{* * *}$ & $5.808^{* * *}$ & $8.679^{* * *}$ & $10.606^{* * *}$ \\
\hline & $(8.75)$ & (13.46) & $(14.23)$ & $(9.15)$ & $(14.65)$ & (16.23) \\
\hline $\mathrm{N}$ & 2693 & 4975 & 4446 & 2693 & 4975 & 4446 \\
\hline adj. R-sq & 0.225 & 0.273 & 0.338 & 0.264 & 0.284 & 0.357 \\
\hline
\end{tabular}


Panel B (lateral dispersion)

\begin{tabular}{|c|c|c|c|c|c|c|}
\hline \multirow[b]{2}{*}{ VARIABLES } & \multicolumn{3}{|c|}{$\mathrm{u} \_\mathrm{R}$} & \multicolumn{3}{|c|}{$\mathrm{u}_{-} \mathrm{Q}$} \\
\hline & $\begin{array}{l}\text { Growth } \\
\text { stage }\end{array}$ & $\begin{array}{l}\text { Maturity } \\
\text { stage }\end{array}$ & $\begin{array}{l}\text { Recession } \\
\text { stage }\end{array}$ & $\begin{array}{l}\text { Growth } \\
\text { stage }\end{array}$ & $\begin{array}{l}\text { Maturity } \\
\text { stage }\end{array}$ & $\begin{array}{c}\text { Recession } \\
\text { stage }\end{array}$ \\
\hline \multirow[t]{2}{*}{ rel200 } & -0.000 & $-0.000^{*}$ & -0.000 & $-0.011^{* * *}$ & $-0.007^{\star * *}$ & $-0.006^{\star *}$ \\
\hline & $(-0.54)$ & $(-1.77)$ & $(-1.50)$ & $(-2.90)$ & $(-2.92)$ & $(-2.26)$ \\
\hline \multirow[t]{2}{*}{ lev } & 0.016 & $0.052^{\star * *}$ & $0.046^{\star * *}$ & $-0.961^{* * *}$ & $0.425^{\star}$ & $1.054^{* * *}$ \\
\hline & (1.45) & $(8.00)$ & (9.58) & $(-3.10)$ & $(1.88)$ & $(4.62)$ \\
\hline \multirow[t]{2}{*}{ lnboard } & 0.003 & -0.007 & 0.006 & 0.001 & -0.095 & 0.121 \\
\hline & $(0.61)$ & $(-1.58)$ & $(1.22)$ & $(0.00)$ & $(-0.78)$ & $(0.90)$ \\
\hline \multirow[t]{2}{*}{ growth } & -0.000 & 0.001 & -0.000 & $0.099^{* * *}$ & $0.115^{\star * *}$ & $-0.067^{\star *}$ \\
\hline & $(-0.31)$ & $(0.62)$ & $(-0.13)$ & $(2.62)$ & $(4.07)$ & $(-2.03)$ \\
\hline \multirow[t]{2}{*}{ C_size } & $-0.007^{* * *}$ & $-0.011^{* * *}$ & $-0.012^{\star * *}$ & $-0.081^{\star *}$ & $-0.373^{* * *}$ & $-0.547^{\star * *}$ \\
\hline & $(-6.08)$ & $(-12.38)$ & $(-13.41)$ & $(-2.18)$ & $(-8.81)$ & $(-11.87)$ \\
\hline \multirow[t]{2}{*}{$\mathrm{H} 10$} & $0.029^{* * *}$ & $0.027^{* * *}$ & $0.028^{\star * *}$ & $0.742^{* * *}$ & $0.902^{* * *}$ & $0.831^{* * *}$ \\
\hline & $(3.58)$ & $(4.58)$ & $(4.07)$ & $(3.34)$ & $(5.92)$ & $(5.27)$ \\
\hline \multirow[t]{2}{*}{ seperation } & -0.000 & -0.000 & -0.000 & -0.003 & $-0.005^{\star}$ & $-0.008^{* * *}$ \\
\hline & $(-0.62)$ & $(-0.54)$ & $(-1.25)$ & $(-0.72)$ & $(-1.93)$ & $(-3.39)$ \\
\hline \multirow[t]{2}{*}{ age } & $0.001^{* * *}$ & $0.001^{* *}$ & $0.001^{* * *}$ & -0.010 & 0.011 & $0.018^{* *}$ \\
\hline & $(2.76)$ & (2.48) & $(3.01)$ & $(-1.03)$ & $(1.46)$ & $(2.37)$ \\
\hline Year(Ind) & Control & Control & Control & Control & Control & Control \\
\hline \multirow[t]{2}{*}{ _cons } & $0.154^{\star * \star}$ & $0.250^{\star * *}$ & $0.236^{* * *}$ & $3.353^{* * *}$ & $8.781^{* * *}$ & $11.609^{* * *}$ \\
\hline & (5.73) & (13.19) & (13.16) & $(4.32)$ & $(10.94)$ & $(13.52)$ \\
\hline $\mathrm{N}$ & 2693 & 4975 & 4446 & 2640 & 4805 & 4254 \\
\hline adj. R-sq & 0.068 & 0.162 & 0.212 & 0.110 & 0.158 & 0.269 \\
\hline
\end{tabular}

Note: 1$)^{* * *},{ }^{* *},{ }^{*}$ indicate significant at $1 \%, 5 \%$, and $10 \%$, respectively; 2$) t$ values in parentheses.

regression results show that in the two models, the dummy variable dum(rel200) is significantly negatively correlated with the accounting performance (Std_ROA) and market performance (Std_TobinQ) which are proxy variables for corporate performance volatility, supporting the hypothesis H1. 3) Adding rel200* ${ }^{\star} \mathrm{SOE}$ to the model. The regression results show that the coefficient of enterprise nature (SOE) and Buddhist tradition (rel200) are significantly negative, while the coefficient of rel200*SOE is significantly positive, which indicates that the suppression of performance fluctuations of Buddhist tradition exists in enterprises of different natures. A certain degree of difference, compared with non-state-owned enterprises, the Buddhist tradition has reduced the suppression of performance fluctuations of state-owned enterprises, further validating the hypothesis H2. 4) Using the multivariate scoring method to divide the enterprise life cycle, the final regression results show that when the enterprise is in the mature stage of the life cycle, the coefficients of the traditional Buddhist culture (rel200) are signifi- 
cantly negative, further verification the hypothesis $\mathrm{H} 3$.

\section{Conclusions}

\subsection{Contribution}

1) Empirical contribution

First, from the company level, an enterprise is an organization that seeks to maximize profits. However, as a company's decision makers and executives, executives' personal characteristics will have an impact on the stability of company performance through certain behavioral decisions. Performance is one of the most concerned issues for corporate stakeholders. Stakeholders have different levels of acceptability for fluctuations in business performance due to different biases toward risk. Therefore, this paper studies the influence of traditional Buddhist culture (corporate culture) on corporate performance volatility, stressing those enterprises should not neglect the role of corporate culture in the development process, and provide reference and reference for realizing the long-term interests of the company.

Second, for the enterprise itself, it is necessary to recognize the impact of the external environment of the enterprise on the entire enterprise organization and corporate decision-makers. Therefore, the development of the enterprise must consider the joint effect of the internal and external environment and grasp the external advantages of the enterprise development.

2) Theoretical contribution

In addition to the actual contribution, the research in this paper has certain theoretical significance. At present, the research on corporate performance volatility is still limited to the literature related to corporate governance, while the relative non-institutional considerations are relatively rare, especially from the perspective of Chinese traditional culture.

First, company performance includes two dimensions of performance level and performance volatility, which can measure the management level of executives. However, some related researches mainly focus on the performance level of the company, and less people study the performance volatility of the company. It not only represents whether the company's profitability has certain stability, but also reflects the risks faced by enterprises in the process of business management. Therefore, this paper mainly explores the influence of the non-institutional culture of Buddhist tradition on the performance fluctuation of the company, enriching the research in this field.

Second, most of the listed companies in China are state-owned listed companies, which may have some unique characteristics by nature. The internal corporate culture formed by them also has special attributes. Therefore, according to the unique attributes of Chinese listed companies and the unique internal culture of enterprises, it is studied whether there is a difference between traditional Buddhist culture and corporate performance waves under the different property rights. 
Third, most of the previous studies have taken the static view of the listed companies as a research sample, ignoring the differences between enterprises at different stages of life cycle. In view of this, this paper introduces the enterprise life cycle theory to investigate whether there is a difference in the influence of traditional Buddhist culture on enterprise performance fluctuations in different life cycle stages, and attempts to provide a reference for the non-institutional culture to dynamically construct enterprise performance fluctuations in different life cycle stages of enterprises.

\subsection{Conclusion and Future Research Direction}

This paper is based on the idea that Buddhist traditional culture can enhance individual ethical standards and internal self-discipline, and then explores the relationship between traditional Buddhist culture and corporate performance fluctuations. Different from previous research literatures on economic development, political structure and legal system, and corporate governance, this paper focuses on the impact of corporate culture-traditional Buddhist culture which is the implicit social norms on corporate performance volatility. The empirical results show that the traditional culture of Buddhism plays an important positive role in restraining the fluctuation of corporate performance. The main findings include: The stronger the traditional Buddhist culture of listed companies is, the smaller the fluctuation of corporate performance is; Compared with state-owned enterprises, the negative impact of traditional Buddhist culture on fluctuations in corporate performance is stronger among non-state-owned enterprises; When the company is in a mature period, the Buddhist tradition has a stronger inhibitory effect on corporate performance fluctuations. The limitations of this paper are mainly as follows: first, because of the Buddhist belief involving personal privacy issues, it is difficult to collect data at the individual level. Therefore, this paper does not consider whether there are differences in the impact of different religious belief categories on corporate performance fluctuations. Second, the traditional Buddhist culture is only part of the corporate culture. Therefore, there is still a lot of room for the study of corporate culture in the future.

\section{Conflicts of Interest}

The authors declare no conflicts of interest regarding the publication of this paper.

\section{References}

[1] Cheng, S. (2008) Board Size and the Variability of Corporate Performance. Journal of Financial Economics, 87, 157-176. https://doi.org/10.1016/j.jfineco.2006.10.006

[2] Adams, R.B. and Ferreira, D. (2005) Powerful CEOs and Their Impact on Corporate Performance. Review of Financial Studies, 18, 1403-1432. https://doi.org/10.1093/rfs/hhi030

[3] Li, S.N. and Niu, J.B. (2009) Re-Study on the Independence Value of Board of Directors-Based on the Analysis of the Impact of Performance Fluctuation. The 
Theory and Practice of Finance and Economics, 30, 81-85.

[4] Zang, M.J. (2015) Women's Proportion of Board of Directors and Corporate Performance Volatility. Dongbei University of Finance and Economics, Dalian.

[5] Chen, T. (2015) Institutions, Board Structure, and Corporate Performance: Evidence from Chinese Firms. Journal of Corporate Finance, 32, 217-237. https://doi.org/10.1016/j.jcorpfin.2014.10.009

[6] Du, X. (2014) Does Religion Mitigate Tunneling? Evidence from Chinese Buddhism. Journal of Business Ethics, 125, 299-327. https://doi.org/10.1007/s10551-013-1917-6

[7] Du, X. (2013) Does Religion Matter to Owner Manager Agency Costs? Evidence from China. Journal of Business Ethics, 118, 319-347. https://doi.org/10.1007/s10551-012-1569-y

[8] Kumar, A., Page, J.K. and Spalt, O.G. (2011) Religious Beliefs, Gambling Attitudes, and Financial Market Outcomes. Journal of Financial Economics, No. 3, 82. https://doi.org/10.1016/j.jfineco.2011.07.001

[9] McGuire, S.T., Omer, T.C. and Sharp, N.Y. (2011) The Impact of Religion on Financial Reporting Irregularities. The Accounting Review, 87, 645-673. https://doi.org/10.2308/accr-10206

[10] Nickell, S.J. (1993) Competition and Corporate Performance. Journal of Political Economy, 104, 724-746. https://doi.org/10.1086/262040

[11] Du, X.Q., Wei, W., Zeng, Q. and Chang, Y.Y. (2016) Religious Influence, Controlling Shareholder and Over-Investment: Empirical Evidence Based on Chinese Buddhism. Accounting Research, No. 08, 50-57+97.

[12] Du, Y.J. and Feng, W.Z. (2014) Religion, Political Connection and Donation Behavior: Based on Empirical Evidence of Chinese Listed Companies. Contemporary Finance and Economics, No. 06, 111-112.

[13] Chen, D.H., Hu, X.L., Liang, S.K. and Xin, F. (2013) Religious Tradition and Corporate Governance. Economic Research, 48, 71-84.

[14] Yang, J.D. and Liu, C. (2013) Does the Authority of Senior Management Affect the Performance Fluctuation of the Company? Economic Theory and Economic Management, No. 8, 72-83.

[15] Yu, M.G., Li, W.G. and Pan, H.B. (2013) Manager Overconfidence and Corporate Risk Taking. Financial Research, No. 1, 149-163.

[16] Ruan, R.P., Zheng, F.T. and Liu, L. (2014) The Power of Faith: Is Religion Conducive to Entrepreneurship? Economic Research, No. 3, 171-184.

[17] Li, C.C. and Wang, X.Y. (2013) Comparison and Enlightenment of the Differences between Eastern and Western Business Ethics in the Perspective of Religious Culture. Business Economics and Management, No. 11, 54-60.

[18] Zhu, J.G., Ye, K.T. and Yan, D. (2012) Research on Risk Avoidance and Corporate Investment Behavior of Female Directors-Based on the Perspective of Financial Crisis. Finance \& Trade in Economics, No. 4, 50-58.

[19] Ruan, R.P. and Wang, B. (2011) Religious Belief and Trust under the Pattern of Difference-Based on the Empirical Data of Ten Cities in China. Society, 31, 195-217.

[20] Ruan, R.P. and Liu, L. (2011) Research on the Supply of Informal Social Security in Rural China-Based on the Analysis of Religious Social Security Function. Management World, No. 4, 46-57+187-188. 
[21] Huang, L.Q., Fu, Y.L. and Qu, Y.H. (2010) Manager Overconfidence, Tax Shield Turning Point and Corporate Performance. Management Science, 24, 10-19.

[22] Rao, Y.L. and Wang, J.X. (2010) Empirical Research on CEO Overconfidence, Board Structure and Company Performance. Management Science, 23, 2-13.

[23] Quan, X.F. and Wu, S.N. (2010) The Power of CEO, the Quality of Information Disclosure and the Volatility of Company Performance-An Empirical Study Based on Listed Companies in Shenzhen Stock Exchange. Nankai Management Review, 13, 142-153.

[24] Li, S.G. and Niu, J.B. (2009) Re-Study on the Scale Value of Board of Directors in Family Enterprises-Based on the Integration Analysis of Performance Fluctuation and Performance Level. Economic Management, 31, 120-125.

[25] Niu, J.B. and Li, S.N. (2007) The Listing Method, Board Structure and Enterprise Value of Private Companies-Based on the Comparative Study of Panel Data of Private Listed Companies in China. Management Science, No. 02, 15-24.

[26] Niu, J.B. (2009) Research on Governance Effect of Board Size-Based on New Explanation of Performance Fluctuation. Journal of Zhongnan University of Economics and Law, No. 1, 112-118.

[27] Li, L., Liu, F.W. and Lu, W.B. (2009) Research on the Governance Effect of Equity Check and Balance Based on the Volatility of Corporate Performance. Management World, No. 5, 145-151.

[28] Wu, C.P., Wu, S.N. and Zheng, F.Q. (2008) Theoretical and Empirical Research on Manager Behavior and Continuous M\&A Performance. Management World, No. 7, 126-133. 